\title{
The Nuclear Lamina as a Gene-silencing Hub
}

\author{
Yuri Y. Shevelyov ${ }^{1 *}$ and Dmitry I. Nurminsky ${ }^{2}$ \\ 1 Department of Molecular Genetics of Cell, Institute of \\ Molecular Genetics, Russian Academy of Sciences, 123182, \\ Kurchatov Sq. 2, Moscow, Russia \\ 2 Department of Biochemistry and Molecular Biology, \\ University of Maryland School of Medicine, 108 N. Greene \\ St., Baltimore, MD 21201, USA
}

\begin{abstract}
There is accumulating evidence that the nuclear periphery is a transcriptionally repressive compartment. A surprisingly large fraction of the genome is either in transient or permanent contact with nuclear envelope, where the majority of genes are maintained in a silent state, waiting to be awakened during cell differentiation. The integrity of the nuclear lamina and the histone deacetylase activity appear to be essential for gene repression at the nuclear periphery. However, the molecular mechanisms of silencing, as well as the events that lead to the activation of lamina-tethered genes, require further elucidation. This review summarizes recent advances in understanding of the mechanisms that link nuclear architecture, local chromatin structure, and gene regulation.
\end{abstract}

\section{The makeup of nuclear periphery}

The nuclear periphery is demarcated by two layers of nuclear membranes that are separated by the perinuclear space. The membranes are perforated with nuclear pores, which are multi-subunit nucleoporin complexes that mediate the selective transport of macromolecules. The inner nuclear membrane is lined with the nuclear lamina, a meshwork of type $\mathrm{V}$ intermediate filaments lamins (reviewed in Melcer et al., 2007; Prokocimer et al., 2009). The nuclear lamina is ubiquitous in all multicellular eukaryotes. Its multiple functions are both structural and regulatory - the lamina supports the mechanical stability of the nucleus and its attachment to the cytoskeleton, and contributes to the control of gene expression, chromosome replication, and genome stability. The number of lamin-coding genes per genome varies from one in nematodes to three in mammals. Lamins are classified based on their expression patterns: Type B lamins are ubiquitously expressed and mostly localized at the nuclear periphery (e.g. encoded by $I m n-1$ in nematodes, $D m O$ in flies, and LMNB1 and LMNB2 in mammals), and types $A / C$ are expressed in specific cell types and are present throughout the nucleus (examples include those encoded by lamC in flies and LMNA in mammals).

Lamins interact with many integral proteins of the inner nuclear membrane (reviewed in Schirmer and Foisner, 2007). These proteins, as well as the lamins themselves, can bind both the chromatin and a number of chromatinmodifying proteins and other transcriptional regulators. The resulting elaborate nucleoprotein meshwork at the nuclear periphery can serve as a structural foundation for gene-

\section{*Corresponding author: shevelev@img.ras.ru}

regulatory interactions (Höger et al., 1991; Glass et al., 1993; Luderus et al., 1994; Goldberg et al., 1999; Stierle et al., 2003; Foisner and Gerace, 1993; Furukawa et al., 1997; Polioudaki et al., 2001; Dechat et al., 2004; Makatsori et al., 2004). Mutations in lamins and lamin-associated proteins are linked to tissue degenerative disorders collectively termed laminopathies (reviewed in Dauer and Worman, 2009). Nuclei of laminopathic cells show disorganization and loss of peripheral heterochromatin (Goldman et al., 2004) which is normally in contact with the lamina (Belmont et al., 1993; Schermelleh et al., 2008). This suggests that the integrity of the lamin-associated meshwork is essential for the maintenance of the peripheral gene-silencing compartment. It is noteworthy that the nuclear pores penetrate the membrane at the sites devoid of both the lamina and associated heterochromatin (Belmont et al., 1993; Schermelleh et al., 2008), thus probably marking the distinct peripheral regions not associated with gene silencing.

\section{Intranuclear chromosome positioning is not random}

When chromosomes are orderly positioned within interphase nuclei - such as in the Drosophila embryonic blastoderm where the telomeres are clustered in the apical part of the nucleus and the centromeres are in the basal part (so-called Rabl orientation) - the radial coordinates of the chromosome regions are pre-determined (Marshall et al., 1996; Lowenstein et al., 2004). There is accumulating evidence that programmed radial positioning of chromosome loci and entire chromosomes also occurs in interphase nuclei that appear less organized, such as in mammals. For example, 2D-FISH (fluorescence in situ hybridization) analysis of human cells revealed that throughout the entire interphase, the gene-dense chromosomes localized close to the center of the nucleus whereas the gene-poor chromosomes showed more peripheral localization (Croft et al., 1999; Boyle et al., 2001). More detailed 3D-FISH studies demonstrated that unlike in rounded cells, the chromosome size becomes the major factor in defining radial positioning in flattened cells, such as fibroblasts. In flattened cells, larger chromosomes are peripherally located (Bolzer et al., 2005). Similar observations have been made in mice (Mayer et al., 2005) and other mammals (reviewed in Cremer and Cremer, 2010).

Although following the general trends described above, chromosome positioning significantly varies between individual nuclei and probably changes within a single nucleus over time. However, the orientation of the chromosome territory in the interphase nucleus tends to be conserved. Gene-dense and gene-poor chromosome segments form distinct non-overlapping clusters, as seen in Drosophila (Boutanaev et al., 2005) and mammals (Federico et al., 2008). These findings are consistent with the description of two chromosome compartments revealed in human cells by the $\mathrm{Hi}-\mathrm{C}$ (chromosome conformation capture combined with high-throughput DNA sequencing) approach: One compartment contains silent, gene-poor, and "closed" chromatin and the other contains "open" and 
actively transcribed chromatin. Of note, chromosome regions within each of these compartments appeared closer to each other than the regions belonging to different compartments (Lieberman-Aiden et al., 2009).

With regard to the orientation within the nucleus, genepoor chromosome regions often face the periphery and the gene-dense regions are located closer to the center of the nucleus (Saccone et al., 2002; Küpper et al., 2007). Overall, gene-dense chromatin regions (which can be revealed by FISH because of their enrichment with Alu repeats) do not overlap with the peripheral gene-poor chromatin (Bolzer et al., 2005). Exceptions do exist, including retinal rod cells in which gene-poor heterochromatin is densely packed at the center of the nucleus and probably improves light perception while the euchromatin is at nuclear periphery (Solovei et al., 2009). But, overall, observations indicate that the nuclear periphery usually represents the compartment filled with inactive, compact, and gene-poor chromatin.

\section{Nuclear envelope contacts with distinct, well-defined chromosome segments}

The guiding role of interactions between the chromatin and nuclear envelope in chromosome positioning has been suggested long ago (Comings, 1968). Cytological observations of the giant polytene chromosomes in Drosophila salivary glands identified fifteen euchromatic chromosome segments that were consistently in contact with the nuclear periphery (Hochstrasser et al., 1986). Although they were located in euchromatic chromosome arms, these segments almost perfectly coincided with the so-called "intercalated heterochromatin" which is characterized by under-replication and ectopic contacts in polytene chromosomes; these are features usually found in heterochromatic regions (Zhimulev et al., 1982). Consistent with this observation, late replicating chromatin was predominantly found in the peripheral nuclear compartment (Ferreira et al., 1997). Further study of the Drosophila embryonic blastoderm using multiple FISH probes showed that about one-half of the analyzed chromosome regions were located at the nuclear periphery. By extrapolation, the authors suggested that at least 75 chromosome segments in Drosophila genome were in contact with the nuclear envelope (Marshall et al., 1996).

More precise mapping of the lamina-interacting genome regions became possible with the advent of a technique called DamID (DNA adenine methyltransferase (Dam) in vivo identification of chromatin protein-DNA interactions) (van Steensel and Henikoff, 2000). This approach was applied to the Drosophila embryonic cell line $\mathrm{Kc}$ for identification of the genome sequences methylated by a protein fusion of Dam and B-type lamin (Pickersgill et al., 2006). Of the approximately $60 \%$ of Drosophila genes present on the cDNA microarray used in this study, about 500 genes $(\sim 5 \%)$ were identified as lamina-associated. Later, similar studies on human fibroblasts (Guelen et al., 2008) and different types of mouse cells (Peric-Hupkes et al., 2010) utilized tiling genome microarrays, which allowed the investigators to map the interactions with the lamina across both coding and non-coding sequences. This led to the identification of over 1300 lamina-associated domains (LADs) ranging in size from 0.1 to $10 \mathrm{Mb}$ (with the median size of $0.5 \mathrm{Mb}$ ) and covering about $40 \%$ of genome. About one-quarter of lamina-associated sequences were taken out of consideration in these studies as not fitting additional LAD definitions, so altogether approximately one-half of the mammalian genome was detected as interacting with the lamina. LADs turned out to be mostly gene-poor regions containing only $13-18 \%$ of all genes (Guelen et al., 2008; Peric-Hupkes et al., 2010), akin to the "gene deserts" (Venter et al., 2001). Similar results were obtained in recent DamID mapping of lamina-binding regions in Drosophila using tiling arrays. The study showed that LADs (which are smaller in this species with the median size of $90 \mathrm{~kb}$ ) have a 1.5-fold decreased gene density (van Bemmel et al., 2010). These findings are consistent with the earlier observations that placed gene-poor chromatin at the nuclear periphery.

Intriguingly, even though the pattern of alternating LADs and interLADs appears to be conserved in metazoans, deviations from this trend can be seen in some cases. For example, in C. elegans, whole-genome ChIP mapping of regions in contact with the nuclear lamina protein, LEM-2 (lkegami et al., 2010), showed the typical LAD/interLAD pattern in the chromosome arms but revealed the large central regions to be devoid of contacts. This observation may indicate that the central parts of $C$. elegans chromosomes are looping away from the nuclear periphery. However, it is also possible that the central regions of the chromosomes interact with other components of nuclear lamina instead of LEM-2.

Because protein fusions of Dam and B-type lamins localize to the nuclear envelope, it is tempting to suggest that LADs correspond to the genome regions attached to the lamina and interLADs represent chromosome segments looping toward the center of the nucleus (Figure 1A). However, when individual nuclei were analyzed by FISH in the same cultured cells used for the DamID analysis, it turned out that the "lamina-bound" genes detected by DamID were found away from nuclear periphery, albeit at lower frequency than their "non-lamina-bound" counterparts (Pickersgill et al., 2006; Guelen et al., 2008). Because DamID can detect transient interactions and is cumulative for the duration of the cell cycle (Greil et al., 2006), these data apparently reflect an increased frequency of lamina interactions for LADs in the cell population or in a given cell over time rather than a snapshot picture.

Further, in Drosophila cells, randomly chosen chromosomal loci were found at micron distances from the nuclear periphery (Marshall et al., 1996; Lowenstein et al., 2004). The 50-kb median length of the interLAD in the Drosophila genome (estimated from data of van Bemmel et al., 2010) would be probably not long enough to create these micron-sized loops which would require genome segments on the megabase scale, if a normal 15- to 28fold compaction of the chromatin above the $30-\mathrm{nm}$ fiber is considered (Lowenstein et al., 2004). Even though certain actively transcribed regions can lose compactness and be detected as an unraveled fiber by FISH (Chambeyron and Bickmore, 2004), this is hardly a general phenomenon. Hence, it is unlikely that interLADs would be frequently found at an appreciable distance from nuclear periphery while flanking LADs were tethered to the lamina.

It appears, therefore, that there are two tiers of regulation of the chromosome locus positioning in the nucleus with respect to the nuclear envelope. The average distance of chromatin fiber from the lamina likely depends on the ratio of LADs/interLADs calculated at a megabase scale because 


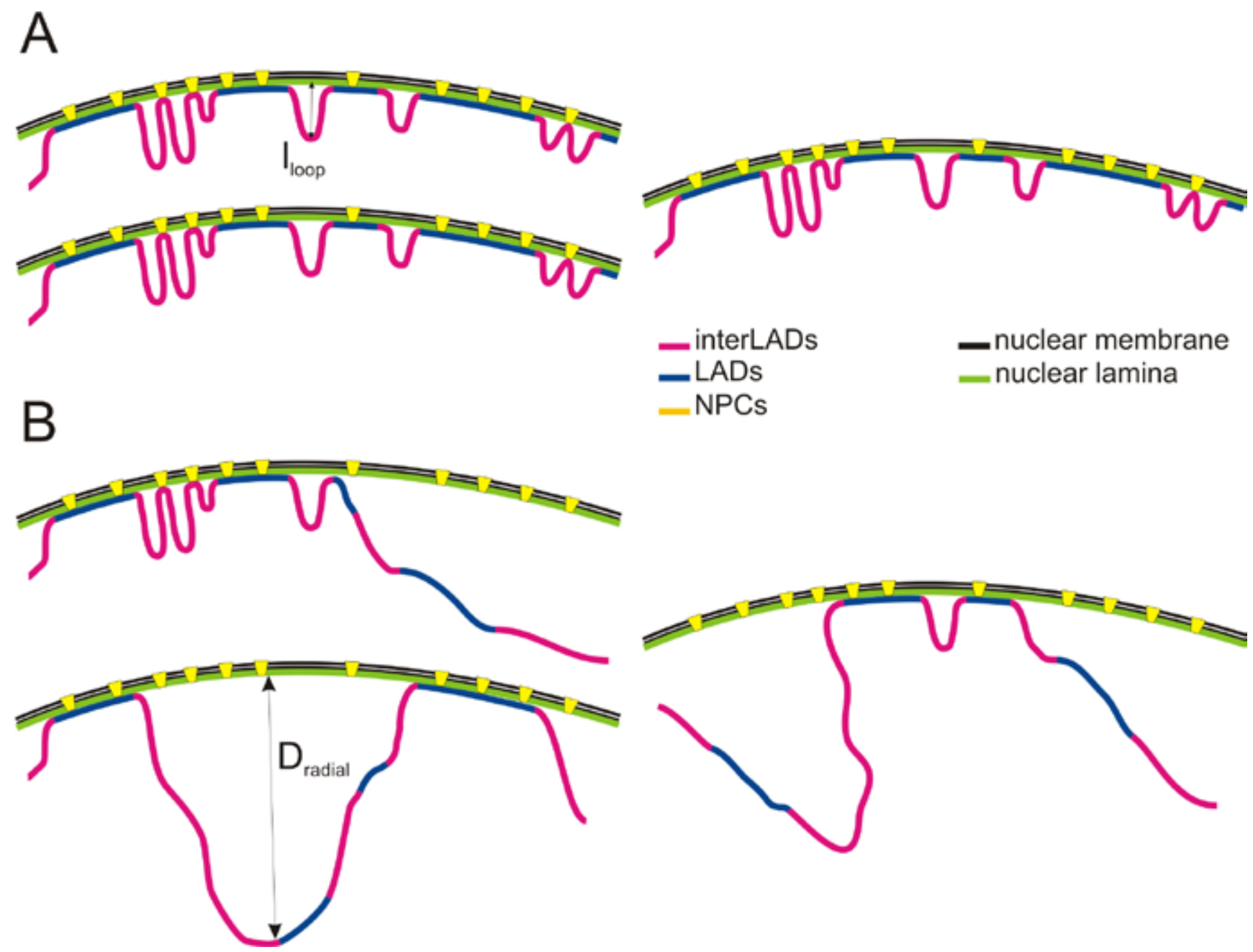

Figure 1. The relationship between $L A D /$ interLAD profile and the distance between chromosome fiber and the nuclear envelope. (A) Model is based on simultaneous attachment of all LADs to the lamina with interLADs looping into nuclear interior. This model is not consistent with the small median length of interLAD loop (l $\left.\mathrm{l}_{\mathrm{loop}}\right)$ in Drosophila $(\sim 50 \mathrm{~kb})$, which may be insufficient to reach micron-scale distances from periphery as detected by FISH. (B) Model is based on transient proximity of large chromosome regions to the nuclear periphery. When chromatin fiber is close to the periphery, LADs, mostly represented by silent chromatin, contact lamina but interLADs, which correspond to active chromatin, do not. Short DNA regions both in LADs and interLADs contact nuclear pores. What determines the average radial distance of chromosome fiber $\left(D_{\text {radial }}\right)$ is currently unknown, although in mammals it is related to the LAD/interLAD ratio on a megabase scale. Note that chromatin fiber is drawn smooth for simplicity.

a good correlation between the fraction of log2(laminB1)-positive probes and the average radial distance from periphery determined by FISH has been observed in mammals (Guelen et al., 2008; Peric-Hupkes et al., 2010), and averaged log2(lamin-B1) values correspond well to the nuclear envelope-associated chromosome regions in the polytene nuclei of Drosophila (Pickersgill et al., 2006; Hochstrasser et al., 1986; Hochstrasser and Sedat, 1987; Mathog and Sedat, 1989). At the same time, the specific pattern of LADs and interLADs on a smaller scale, which is particularly pertinent to Drosophila, probably reflects a preferential attachment of the silent LADs versus the active interLADs to the lamina when the chromatin fiber is at the nuclear periphery (Figure 1B).
Changes in chromatin interactions with the nuclear lamina may depend on cell cycling due to the increased chromatin movement in early G1 (Tumbar and Belmont, 2001; Walter et al., 2003; Thomson et al., 2004). Alterations in the pattern of lamina binding across the genome can also occur during development: Analysis of mouse embryonic stem (ES) cells differentiating into neural precursors and further into astrocytes showed that $13-27 \%$ of LADs were not conserved between these different, albeit related, cell types. The important implication of these findings is the dynamic nature of the interactions between the chromosomes and the nuclear lamina, which may contribute to variability of gene expression. 


\section{Nuclear lamina as a gene-silencing hub}

The genes found in contact with the lamina in cultured Drosophila cells, with rare exceptions, are not expressed in these cells (Pickersgill et al., 2006; van Bemmel et al., 2010). Similarly, mammalian LADs contain mostly silent genes with low levels of promoter-associated RNA polymerase II activity and an average expression level that is an order of magnitude lower than that of the interLADs (Guelen et al., 2008; PericHupkes et al., 2010). It makes LADs akin to the previously described low gene expression regions termed "anti-Ridges" (Versteeg et al., 2003; Göetze et al., 2007). In C. elegans, LEM-2 subdomains also show lower gene expression than their "gap" counterparts (Ikegami et al., 2010). Thus, the nuclear periphery is a preferred location for inactive or poorly transcribed genes. Moreover, recent findings strongly indicate that the silent chromatin environment at the nuclear periphery can cause gene repression. In mammals, transcription of transgenes integrated into "antiRidges" is significantly suppressed (Gierman et al., 2007). Similarly, in Drosophila transgenes integrated in the "black" chromatin regions (highly overlapping with LADs) are three times more likely to show mini-white variegation (Babenko et al., 2010; Filion et al., 2010). As long as interactions with the nuclear lamina appear to correlate with gene silencing, the question becomes what comes first: binding to lamina or gene inactivation?

The role of the nuclear lamina in gene silencing was directly tested in studies in which chromosome loci were artificially tethered to the nuclear periphery. These experiments utilized the model in which recognition sites for a DNA binding protein were introduced into a chromosome locus by a transgene insertion. Tethering to the nuclear periphery was achieved by expressing a DNA binding protein fused to an integral membrane protein (Andrulis et al., 1998) or a lamina component (Finlan et al., 2008; Reddy et al., 2008; Dialynas et al., 2010). In yeast, recruitment of a repressible endogenous HMR locus to the nuclear periphery caused its silencing (Andrulis et al., 1998). In Drosophila, recruitment of reporter genes to the lamina resulted in their significant down-regulation (Dialynas et al., 2010). In mammals, some of the endogenous genes surrounding the tether site were down-regulated 2-4 fold upon recruitment to the lamina, with the repression covering remarkably broad regions up to $2 \mathrm{Mb}$ away from the tether (Finlan et al., 2008; Reddy et al., 2008). Thus, at least in some cases, the presence of the chromosome segment at the nuclear periphery is sufficient to cause transcriptional repression. Moreover, the nuclear lamina itself appears to play an active role in repression because disruption of the lamina by ablation of type B lamin in Drosophila (Shevelyov et al., 2009) or by depletion of lamin or its interacting partners in nematode (Towbin et al., 2011) caused up-regulation of genes at the nuclear periphery.

The mechanisms responsible for gene silencing at the nuclear lamina are not fully understood, yet accumulating evidence indicates that diverse conduits may be involved. Lamina-associated proteins can mediate inhibition of transcriptional activators, either by directly sequestering them from the nucleoplasm or by inhibiting their activity through protein interactions. Such mechanism would affect gene expression both at the lamina and throughout the nucleus (reviewed in Heessen and Fornerod, 2007). Moreover, multiple repressors docked to the lamins and lamina-associated proteins may act upon genes tethered to the nuclear lamina, and this model appears to be most relevant to gene silencing at the nuclear periphery. Laminabound genes in Drosophila show a low level of histone acetylation (Pickersgill et al., 2006) and deacetylation of histones occurs in mammals upon artificial recruitment of chromosome segments to the nuclear envelope (Reddy et al., 2008). In addition, mammalian, Drosophila, and nematode LADs are enriched in the gene repressionassociated H3K27me3 histone marks (Guelen et al., 2008; Peric-Hupkes et al., 2010; Filion et al., 2010; Ikegami et al., 2010). Thus, two major mechanisms involving histone modifications may act at nuclear lamina: one centered on histone deacetylation and the other focused on histone methylation.

Class I histone deacetylases, including HDAC1 and HDAC3, can bind to the lamina-associated LEM domain proteins, such as Lap2 $\beta$ and Emerin. At least one of these enzymes, HDAC3, appears to require this interaction for full activity (Somech et al., 2005; Holaska and Wilson, 2007). Consistent with these findings, low histone acetylation has been observed in the peripheral nuclear compartment (Sadoni et al., 1999). Moreover, a Class I/II HDAC inhibitor trichostatin A (TSA) relieves repression of the lamina-tethered genes (Finlan et al., 2008) and causes a prominent increase in histone acetylation at the nuclear periphery (Gilchrist et al., 2004). In addition to a potential role in regulation of gene expression through histone deacetylation, Class I/II HDACs may control the attachment of chromatin to the lamina because TSA treatment can cause translocation of the lamina-bound genes away from nuclear periphery (Zink et al., 2004; Pickersgill et al., 2006). However, interpretation of the TSA experiments requires some caution as they are subject to the potential caveat of inhibitor side effects, and the roles of particular HDAC enzymes in repression at the nuclear periphery are not yet clear.

Enrichment of H3K27me3 in LADs suggests that this histone modification, which is associated with Polycomb repression (Schwartz et al., 2006; reviewed in Beisel and Paro, 2011), may contribute to the silencing effect of the lamina. Polycomb response elements in the repressed state are preferentially found at the nuclear periphery (Fedorova et al., 2008). In C. elegans, the enrichment of large tandem arrays of transgenes silenced at the nuclear periphery with $\mathrm{H} 3 \mathrm{~K} 27 \mathrm{me} 3$ and $\mathrm{H} 3 \mathrm{~K} 9 \mathrm{me} 3$ also indicates a methylation-dependent silencing mechanism, which appears to be dependent on LEM domain proteins and the chromatin-tethering protein BAF (Towbin et al., 2011). It is not clear, however, to what extent large heterochromatinized transgene arrays are reminiscent of the developmentally repressed lamina-associated gene clusters which are mostly represented by diverse and unrelated genes (Boutanaev et al., 2002; Shevelyov et al., 2009).

Mammalian LADs (but not Drosophila LADs and nematode LEM2 domains) are also enriched with H3K9me2 (Guelen et al., 2008; Peric-Hupkes et al., 2010; Filion et al., 2010; Ikegami et al., 2010), which is linked to the spreading of heterochromatin by an HP1-dependent mechanism. HP1 may be tethered to the nuclear lamina via the lamin B receptor (Ye and Worman, 1996). However, in Drosophila, only a small proportion of lamina-bound genes interact with Polycomb or HP1 (Pindyurin et al., 2007; Shevelyov 
et al., 2009; Filion et al., 2010), indicating that at least in this species, such mechanisms may not provide the major contribution to lamina-associated gene silencing. Further, in mammals, a loss of $\mathrm{H} 3 \mathrm{~K} 9 \mathrm{me} 2$ at the nuclear periphery induced by genetic disruption of the major euchromatic H3K9 methyltransferase G9a caused the activation of merely 200 genes (Yokochi et al., 2009), a small fraction compared to the half of mammalian genome present in LADs. However, this microarray study could have missed changes in low copy number transcripts characteristic for LADs, and other repression mechanisms could have compensated for the loss of H3K9me2. Therefore, the role of this histone modification in gene silencing at the nuclear lamina should be further elucidated. Given that H3K9me2 enrichment of mammalian LADs is not evident in embryonic stem cells (Wen et al., 2009; Peric-Hupkes et al., 2010), its role in the regulation of gene expression at the nuclear lamina, if any, may be limited to certain types of differentiated cells (Filion and van Steensel, 2010; Wen et al., 2010). Finally, repression at the nuclear lamina appears to be rather mild (Finlan et al., 2008; Reddy et al., 2008; Shevelyov et al., 2009; our unpublished data) compared to more specialized silencing mechanisms, such as Polycomb-mediated repression. It is likely dedicated to compacting chromatin at the nuclear periphery to reduce its accessibility to transcription machinery and prevent transcriptional "leakage" of silent genes.

\section{Away from the lamina - back to expression?}

Provided that the lamina supports a gene-silencing environment at the nuclear periphery, translocation of the chromosome loci away from the periphery can lead to a loss of transcriptional repression. Indeed, when the dynamics of gene expression and lamina binding were considered in differentiating cells (Peric-Hupkes et al., 2010), loss of contact with the lamina at certain stages of differentiation was predominantly associated with gene activation at the same or next stage. This general pattern was supported by numerous detailed observations of intranuclear positions of individual loci during cell differentiation. Genes that were silent and peripherally located in precursor cells were frequently found translocating away from the nuclear lamina concomitant with their transcriptional activation. Examples include $\mathrm{lgH}$ in the B cell lineage (Kosak et al., 2002), $\beta$-globin in erythroid cells (Ragoczy et al., 2006; Lee et al., 2011), PPARG, FABP4 and GATA2 during adipogenesis (Szczerbal et al., 2009), MASH1 and adjacent genes in neuronal differentiation (Williams et al., 2006), Ssl, Crtp, and adjacent genes in the Drosophila male germline (Shevelyov et al., 2009), and pha-4 during nematode development (Meister et al., 2010). Similarly, the casein gene translocated away from the nuclear periphery in mammary epithelial cells when it was induced by prolactin (Ballester et al., 2008), and a transgenic reporter locus showed the same trend when induced by an artificial trans-activator (Tumbar and Belmont, 2001; Chuang et al., 2006; Meister et al., 2010). Consistent with these findings, a number of genes, such as c-maf in different types of T helpers (Hewitt et al., 2004), and GASZ, CFTR and CORTBP2 in diverse cells (Zink et al., 2004), were found at the nuclear periphery of cells when they are silent, and away from the lamina when expressed. Translocation of activated genes away from the lamina appears to involve chromosome segments of variable size, which may or may not include flanking genes. Zink et al. (2004) found by using FISH that inactive flanking regions can stay at nuclear lamina even though they may be located only 70-250 kb away from the activated loci that are departing from the nuclear periphery. Genome-wide analysis of LADs in differentiating cells (Peric-Hupkes et al., 2010) also implies that activation of a LAD-embedded gene does not disrupt the LAD. Instead, it appears that the active gene selectively reduces its lamina-binding; for instance it may loop out into the nucleoplasm. In other cases, however, entire clusters of coordinately activated genes were found to diminish their lamina binding during differentiation, according to DamID (Peric-Hupkes et al., 2010). FISH data also showed that the activation of a multigenic region during differentiation was associated with translocation of the entire region away from the lamina, including the few genes that are still silent (Williams et al., 2006). These findings imply that the clusters of coordinately expressed genes, which are found on chromosomes of diverse higher eukaryotes may be regulated by virtue of their association with lamina (Boutanaev et al., 2002; Lercher et al., 2002; Roy et al., 2002; Spelman and Rubin, 2002; Ueda et al., 2002; Miller et al., 2004; Williams et al., 2004; Kalmykova et al., 2005; Nelander et al., 2005; Singer et al., 2005; Vogel et al., 2005; Semon et al., 2006; Kosak et al., 2007). Indeed, co-expressed tissue-specific gene clusters are frequently interacting with lamina (Pickersgill et al., 2006; Shevelyov et al., 2009), and the genes with cell type-biased expression are overrepresented in LADs (Filion et al., 2010; our unpublished data).

The departure of genes from the nuclear periphery prior to their transcriptional activation (Kosak et al., 2002; PericHupkes et al., 2010) indicates that detachment from the nuclear lamina poises genes for expression. The concept is strikingly similar to the previously proposed model of chromatin domain potentiation. According to this model, transition from the compacted (closed) to the decondensed (open) configuration of a chromatin domain enables expression of its embedded genes when appropriate transcription factors become available (Kramer et al., 1998; Schübeler et al., 2000; Chambeyron and Bickmore, 2004). It is noteworthy that chromatin domain decondensation appears to be linked to histone acetylation (Krajewski and Becker, 1998; Chen and Townes, 2000; Elefant et al., 2000; Schübeler et al., 2000; Anguita et al., 2001; Yamashita et al., 2002; Myers et al., 2003; Bulger et al., 2003; Chambeyron and Bickmore, 2004). Further, known regulated domains showing the closed/open chromatin transitions are usually present at the nuclear lamina when inactive and translocate centrally when active (Ragoczy et al., 2006; Shevelyov et al., 2009). Moreover, translocation from the nuclear periphery concomitant with chromatin decondensation and gene activation has been described for a transgenic array (Dietzel et al., 2004). Accordingly, chromatin in LADs could possess a compacted higher order conformation and indeed, in Drosophila, LADs are enriched in the linker histone $\mathrm{H} 1$ (Filion et al., 2010). It is tempting, therefore, to suggest that changes in intranuclear position and in chromatin compactness are related and represent the same mechanism where chromatin domains located at the nuclear lamina are deacetylated and "closed" with the embedded genes silenced; detachment of the domains from the nuclear lamina poises the genes for expression because of chromatin acetylation and decondensation. 
The sequence of events that connects gene activation to the detachment from lamina is currently not clear. For example, treatment of cells with an HDAC inhibitor, TSA, leads to the detachment of multiple genes. This indicates that histone deacetylation, and probably chromatin compaction and silencing, may be the factors for peripheral gene localization. However, this detachment effect of TSA may not necessarily be mediated by histone hyperacetylation of lamina-tethered genes because it could be caused by altered acetylation of nonhistone proteins or by secondary effects of TSA-activated regulatory genes. More direct evidence was provided by an analysis of the inducible transgene system, in which binding of a transgene-specific activator caused the departure of transgenic locus from the nuclear periphery (Chuang et al., 2006). Most importantly in these studies, pharmacological inhibition of transcription did not prevent translocation of the transgene, implying that binding of a potent activator and the probable changes in the chromatin structure were sufficient to trigger relocation of the locus away from the nuclear periphery. At the same time, as discussed above, the lamina is laden with transcriptional repressors. It is conceivable that removal of genes from this environment may have caused a loss of their repression.

Despite the fact that mechanisms that keep chromosome regions at the nuclear lamina (and move them away) are not well known, several suggestions have been put forward. Retention at the nuclear periphery may be mediated by specific DNA binding protein(s) capable of interacting with the nuclear lamina. For example, Oct1 can interact with the B type lamin, localizes at nuclear periphery, and has recognition sites preferentially found in LADs (Imai et al., 1997; Malhas et al., 2009; Guelen et al., 2008). Alternatively, lamina-bound factors may be able to recognize repression-associated histone modifications and attract inactive chromatin, a suggestion consistent with the observed loss of attachment caused by gene activation. Translocation of chromosome segments away from nuclear lamina likely involves the nuclear actin and myosin (Chuang et al., 2006; Dundr et al., 2007; Hu et al., 2008; Mehta et al., 2010) and may lead to placement of the activated genes in nuclear compartments favoring transcription (reviewed in Sutherland and Bickmore, 2009). In support of this model, nuclear actin filaments were found associated with transcription-associated inclusions (Kiseleva et al., 2004). However, the above mechanisms are still hypothetical and warrant further elucidation of molecular details.

\section{Bucking the trend: genes expressed at nuclear periphery}

Although the majority of the genes at the nuclear periphery are silent, whole-genome DamID studies identified a small fraction of genes in contact with the nuclear lamina that were expressed (Pickersgill et al., 2006; Guelen et al., 2008; Peric-Hupkes et al., 2010; Filion et al., 2010). FISH studies on individual loci confirmed that active genes, on rare occasions, were localized in the vicinity of the nuclear envelope (Nielsen et al., 2002; Hewitt et al., 2004; Küpper et al., 2007; Szczerbal et al., 2009). Global analysis showed that about $10 \%$ of active chromatin was located close to the nuclear periphery, where hundreds of transcription foci enriched with phosphorylated RNA polymerase II could be found (Luo et al., 2009).
Why is it possible that genes staying at the lamina can escape peripheral gene silencing? One explanation is that repression at the nuclear periphery may be inefficient at shutting down actively transcribed genes. Indeed, forced recruitment of chromosome segments to the lamina did cause repression but the changes in transcript levels was not very efficient, even for the reporter transgenes located right next to the tether site, and ranged from 1.5-fold to 2-fold decrease. Similar or slightly higher down-regulation was observed for some of the endogenous genes surrounding the tether site while others were unaffected (Finlan et al., 2008; Reddy et al., 2008). Therefore, it was not surprising when a tandem array of hundreds of active promoter-driven transgenes was either artificially recruited to the lamina or intrinsically present at nuclear periphery that the transgene expression was not grossly affected (Kumaran and Spector, 2008; Meister et al., 2010). It is possible in some cases that a continuous high promoter activity may confer resistance to silencing even when the gene is at the nuclear lamina. Further, flanking sequences can also contribute to the resistance, as was shown in the studies by Dialynas et al. (2010) where silencing of the transgene by tethering to lamina was dependent on the transgene integration site.

Another mechanism that may contribute to gene expression at nuclear periphery involves the heterogeneity of nuclear envelope. Most of the envelope is lined with lamina but a substantial area is occupied by nuclear pores which appear to penetrate the nuclear membrane in the lamina-free spots (Belmont et al., 1993; Schermelleh et al., 2008). Studies on yeast indicate that many expressed genes are in contact with the nuclear pores (Casolari et al., 2004; Brickner et al., 2004; Cabal et al., 2006; Dieppois et al., 2006; Schmid et al., 2006; Taddei et al., 2006; Köhler et al., 2008; Rougemaille et al., 2008; Ahmed et al., 2010; Light et al., 2010). Similarly, in Drosophila, an active heat shock gene cluster has been shown to associate with the nuclear pores via the Anchoring and mRNA EXport complex (AMEX) (Kurshakova et al., 2007). Recent genomewide studies showed extensive interactions between the nuclear pore proteins (nucleoporins) and transcriptionally active chromatin (Kalverda et al., 2010; Capelson et al., 2010; Vaquerizas et al., 2010). It turned out, however, that some nucleoporins frequently bound to the active chromatin in the nucleoplasm rather than at the nuclear pore sites. Nucleoplasmic nucleoporins apparently act as transcriptional regulators, such as Nup153 and Mtor that contribute to the dosage compensation complex, but their specific influence on the nuclear pore-contacting chromatin is not easy to decipher (Mendjan et al., 2006; Capelson et al., 2010; Vaquerizas et al., 2010). It is possible, for example, that Nup153 is involved in the maintenance of the peripheral localization of the $\mathrm{X}$ chromosome in male somatic tissues where this protein, along with Mtor, cover approximately three-quarters of the chromosome (Vaquerizas et al., 2010). Other nucleoporins, including Sec13, Nup50, Nup62, and Nup98, also interact with active chromatin regions located mostly in nucleoplasm and favor transcription (Kalverda et al., 2010; Capelson et al., 2010).

At the same time, nucleoporins were found in association with inactive chromatin. Specific identification of Nup98-contacting chromatin at the nuclear envelope using DamID with a membrane-tethered Nup98 component revealed interactions with short (median $2 \mathrm{~kb}$ ) chromosome 
regions that had low gene expression and low levels of active chromatin marks, such as H3K4me2 and H4K16Ac (Kalverda et al., 2010). Intriguingly, these sites are rather frequent in the Drosophila genome (one per several dozens of $\mathrm{kb}$ ) and thus occur both in LADs and interLADs. Another Drosophila nucleoporin, Nup88, does not interact with actively expressed chromosome regions (Capelson et al., 2010) and in mammals, Nup93 preferentially interacts with chromatin enriched with repressive modifications H3K9me3 and H3K27me3 (Brown et al., 2008). Taking these factors into consideration, the role of nuclear pores in gene expression at the nuclear periphery in metazoans is not clear and requires further elucidation.

\section{Concluding remarks}

The detailed model of interactions leading to gene regulation at the nuclear lamina will greatly enhance our understanding of developmental gene expression and will provide essential insights into the molecular basis of diseases. Recent progress in studies on the role of the nuclear lamina has uncovered its global influence on gene expression and, in particular, on the activity of developmentally regulated genes. The studies have provided vital background for understanding of the mechanisms underlying the known role of the lamina components in tissue development and homeostasis. It seems likely that gene silencing at the nuclear lamina involves lamina-tethered chromatin modifiers that introduce repressive marks into the chromatin in contact with the lamina; consistent separation from the lamina is associated with accumulation of active chromatin marks and gene expression. However, there are significant challenges ahead to advance our knowledge of the molecular conduits responsible for these effects. A minor fraction of genes are active at nuclear periphery, and the mechanisms conferring their resistance to silencing are poorly understood. In particular, the role of nuclear pores in regulating these genes needs clarification. Further, the forces and structures driving chromosomal movement and positioning are virtually unknown. The interactions between chromatin and lamina appear to be transient, even for the LADs containing silent genes, and it is puzzling why repressive chromatin marks in these regions are not erased when the chromatin is transiently present in nuclear interior. The mechanisms of silencing at nuclear lamina also require further elucidation. Numerous lamina-associated molecules may be involved but the key repressors still have not been identified and the factors that control their placement at specific chromatin loci are not well known. Activation of genes upon their detachment from the lamina is even less understood, and the order of events - whether binding of transactivators and chromatin remodeling causes departure from the lamina or vice versa - is yet to be determined.

\section{Acknowledgments}

This work was supported by the Russian Foundation for Basic Research Grant \#10-04-00669-a, by Grant for Molecular and Cellular Biology from Russian Academy of Sciences, by State Contract \#02.740.11.0288 from Ministry of Education and Science of Russian Federation, and by the National Science Foundation Grant \#0960531.

\section{References}

Ahmed, S., Brickner, D.G., Light, W.H., Cajigas, I., McDonough, M., Froyshteter, A.B., Volpe, T., and Brickner, J.H. (2010). DNA zip codes control an ancient mechanism for gene targeting to the nuclear periphery. Nat. Cell Biol. 12, 111-118.

Andrulis, E.D., Neiman, A.M., Zappulla, D.C., and Sternglanz, R. (1998). Perinuclear localization of chromatin facilitates transcriptional silencing. Nature 394, 592-595.

Anguita, E., Johnson, C.A., Wood, W.G., Turner, B.M., and Higgs, D.R. (2001). Identification of a conserved erythroid specific domain of histone acetylation across the $\alpha$-globin gene cluster. Proc. Natl. Acad. Sci. USA 98, 12114-12119.

Babenko, V.N., Makunin, I.V., Brusentsova, I.V., Belyaeva, E.S., Maksimov, D.A., Belyakin, S.N., Maroy, P., Vasil'eva, L.A., and Zhimulev, I.F. (2010). Paucity and preferential suppression of transgenes in late replication domains of the D. melanogaster genome. BMC Genomics 11, 318.

Ballester, M., Kress, C., Hue-Beauvais, C., Kiêu, K., Lehmann, G., Adenot, P., and Devinoy, E. (2008). The nuclear localization of WAP and CSN genes is modified by lactogenic hormones in $\mathrm{HC} 11$ cells. J. Cell Biochem. 105, 262-270.

Beisel, C., and Paro, R. (2011). Silencing chromatin: comparing modes and mechanisms. Nat. Rev. Genet. 12, 123-135.

Belmont, A.S., Zhai, Y., and Thilenius, A. (1993). Lamin B distribution and association with peripheral chromatin revealed by optical sectioning and electron microscopy tomography. J. Cell Biol. 123, 1671-1685.

Bolzer, A., Kreth, G., Solovei, I., Koehler, D., Saracoglu, K., Fauth, C., Muller, S., Eils, R., Cremer, C., Speicher, M.R., et al. (2005). Three dimensional maps of all chromosomes in human male fibroblast nuclei and prometaphase rosettes. PLoS Biol. 3, e157.

Boutanaev, A.M., Kalmykova, A.I., Shevelyov, Y.Y., and Nurminsky, D.I. (2002). Large clusters of co-expressed genes in the Drosophila genome. Nature 420, 666-669.

Boutanaev, A.M., Mikhaylova, L.M., and Nurminsky, D.I. (2005). The pattern of chromosome folding in interphase is outlined by the linear gene density profile. Mol. Cell. Biol. 25, 8379-8386.

Boyle, S., Gilchrist, S., Bridger, J.M., Mahy, N.L., Ellis, J.A., and Bickmore, W.A. (2001). The spatial organization of human chromosomes within the nuclei of normal and emerin-mutant cells. Hum. Mol. Genet. 10, 211-219.

Brickner, J.H., and Walter, P. (2004). Gene recruitment of the activated INO1 locus to the nuclear membrane. PLoS Biol. 2, e342.

Brown, C.R., Kennedy, C.J., Delmar, V.A., Forbes, D.J., and Silver, P.A. (2008). Global histone acetylation induces functional genomic reorganization at mammalian nuclear pore complexes. Genes Dev. 22, 627-639.

Bulger, M., Schübeler, D., Bender, M.A., Hamilton, J., Farrell, C.M., Hardison, R.C., and Groudine, M. (2003). A complex chromatin landscape revealed by patterns of nuclease sensitivity and histone modification within the mouse $\beta$-globin locus. Mol. Cell. Biol. 23, 5234-5244.

Cabal, G.G., Genovesio, A., Rodriguez-Navarro, S., Zimmer, C., Gadal, O., Lesne, A., Buc, H., Feuerbach-Fournier, F., Olivo-Marin, J.-C., Hurt, E.C., et al. (2006). SAGA interacting factors confine sub-diffusion of transcribed genes to the nuclear envelope. Nature 441, 770-773. 
Capelson, M., Liang, Y., Schulte, R., Mair, W., Wagner, U., and Hetzer, M.W. (2010). Chromatin-bound nuclear pore components regulate gene expression in higher eukaryotes. Cell 140, 372-383.

Casolari, J.M., Brown, C.R., Komili, S., West, J., Hieronymus, H., and Silver, P.A. (2004). Genome-wide localization of the nuclear transport machinery couples transcriptional status and nuclear organization. Cell 117, 427-439.

Chambeyron, S., and Bickmore, W.A. (2004). Chromatin decondensation and nuclear reorganization of the HoxB locus upon induction of transcription. Genes Dev. 18, 1119-1130.

Chen, W.Y., and Townes, T.M. (2000). Molecular mechanism for silencing virally transduced genes involves histone deacetylation and chromatin condensation. Proc. Natl. Acad. Sci. USA 97, 377-382.

Chuang, C.H., Carpenter, A.E., Fuchsova, B., Johnson, T., de Lanerolle, P., and Belmont, A.S. (2006). Long-range directional movement of an interphase chromosome site. Curr. Biol. 16, 825-831.

Comings, D.E. (1968). The rationale for an ordered arrangement of chromatin in the interphase nucleus. Am. J. Hum. Genet. 20, 440-460.

Cremer, T., and Cremer, M. (2010). Chromosome Territories. Cold Spring Harb. Perspect. Biol. 2, a003889.

Croft, J.A., Bridger, J.M., Boyle, S., Perry, P., Teague, P., and Bickmore, W.A. (1999). Differences in the localization and morphology of chromosomes in the human nucleus. J. Cell Biol. 145, 1119-1131.

Dauer, W.T., and Worman, H.J. (2009). The nuclear envelope as a signaling node in development and disease. Dev. Cell 17, 626-638.

Dechat, T., Gajewski, A., Korbei, B., Gerlich, D., Daigle, N., Haraguchi, T., Furukawa, K., Ellenberg, J., and Foisner, R. (2004). LAP2 $\alpha$ and BAF transiently localize to telomeres and specific regions on chromatin during nuclear assembly. J. Cell Sci. 117, 6117-6128.

Dialynas, G., Speese, S., Budnik, V., Geyer, P.K., and Wallrath, L.L. (2010). The role of Drosophila lamin C in muscle function and gene expression. Development 137 , 3067-3077.

Dieppois, G., Iglesias, N., and Stutz, F. (2006). Cotranscriptional recruitment to the mRNA export receptor Mex67p contributes to nuclear pore anchoring of activated genes. Mol. Cell. Biol. 26, 7858-7870.

Dietzel, S., Zolghadr, K., Hepperger, C., and Belmont, A.C. (2004). Differential large-scale chromatin compaction and intranuclear positioning of transcribed versus nontranscribed transgene arrays containing $\beta$-globin regulatory sequences. J. Cell Sci. 117, 4603-4614.

Dundr, M., Ospina, J.K., Sung, M.H., John, S., Upender, M., Ried, T., Hager, G.L., and Matera, A.G. (2007). Actindependent intranuclear repositioning of an active gene locus in vivo. J. Cell Biol. 179, 1095-1103.

Elefant, F., Su, Y., Liebhaber, S.A., and Cooke, N.E. (2000). Patterns of histone acetylation suggest dual pathways for gene activation by a bifunctional locus control region. EMBO J. 19, 6814-6822.

Federico, C., Cantarella, C.D., Di Mare, P., Tosi, S., and Saccone, S. (2008). The radial arrangement of the human chromosome 7 in the lymphocyte cell nucleus is associated with chromosomal band gene density. Chromosoma 117, 399-410.
Fedorova, E., Sadoni, N., Dahlsveen, I.K., Koch, J., Kremmer, E., Eick, D., Paro, R., and Zink, D. (2008). The nuclear organization of Polycomb/Trithorax group response elements in larval tissues of Drosophila melanogaster. Chromosome Res. 16, 649-673.

Ferreira, J., Paolella, G., Ramos, C., and Lamond, A.I. (1997). Spatial organization of large-scale chromatin domains in the nucleus: a magnified view of single chromosome territories. J. Cell Biol. 139, 1597-1610.

Filion, G.J., van Bemmel, J.G., Braunschweig, U., Talhout, W., Kind, J., Ward, L.D., Brugman, W., de Castro, I.J., Kerkhoven, R.M., Bussemaker, H.J., et al. (2010). Systematic protein location mapping reveals five principal chromatin types in Drosophila cells. Cell 143, 212-224.

Filion, G.J., and van Steensel, B. (2010). Reassessing the abundance of $\mathrm{H} 3 \mathrm{~K} 9 \mathrm{me} 2$ chromatin domains in embryonic stem cells. Nat. Genet. 42, 4.

Finlan, L.E., Sproul, D., Thomson, I., Boyle, S., Kerr, E., Perry, P., Ylstra, B., Chubb, J.R., and Bickmore, W.A. (2008). Recruitment to the nuclear periphery can alter expression of genes in human cells. PLoS Genet. 4, e1000039.

Foisner, R., and Gerace, L. (1993). Integral membrane proteins of the nuclear envelope interact with lamins and chromosomes, and binding is modulated by mitotic phosphorylation. Cell 73, 1267-1279.

Furukawa, K., Glass, C., and Kondo, T. (1997). Characterization of the chromatin binding activity of lamina-associated polypeptide (LAP) 2. Biochem. Biophys. Res. Commun. 238, 240-246.

Gierman, H.J., Indemans, M.H.G., Koster, J., Göetze, S., Seppen, J., Geerts, D., van Driel, R., and Versteeg, R. (2007). Domain-wide regulation of gene expression in the human genome. Genome Res. 17, 1286-1295.

Gilchrist, S., Gilbert, N., Perry, P., and Bickmore, W.A. (2004). Nuclear organization of centromeric domains is not perturbed by inhibition of histone deacetylases. Chromosome Res. 12, 505-516.

Glass, C.A., Glass, J.R., Taniura, H., Hasel, K.W., Blevitt, J.M., and Gerace, L. (1993). The a-helical rod domain of human lamins $A$ and $C$ contains a chromatin binding site. EMBO J. 12, 4413-4424.

Göetze, S., Mateos-Langerak, J., Gierman, H.J., de Leeuw, W., Giromus, O., Indemans, M.H.G., Koster, J., Ondrej, V., Versteeg, R., and van Driel, R. (2007). The threedimensional structure of human interphase chromosomes is related to the transcriptome map. Mol. Cell. Biol. 27, 4475-4487.

Goldberg, M., Harel, A., Brandeis, M., Rechsteiner, T., Richmond, T.J., Weiss, A.M., and Gruenbaum, Y. (1999). The tail domain of lamin Dm0 binds histones H2A and H2B. Proc. Natl. Acad. Sci. USA 96, 2852-2857.

Goldman, R.D., Shumaker, D.K., Erdos, M.R., Eriksson, M., Goldman, A.E., Gordon, L.B., Gruenbaum, Y., Khuon, S., Mendez, M., Varga, R., et al. (2004). Accumulation of mutant lamin A causes progressive changes in nuclear architecture in Hutchinson-Gilford progeria syndrome. Proc. Natl. Acad. Sci. USA 101, 8963-8968.

Greil, F., Moorman, C., and van Steensel, B. (2006). DamID: mapping of in vivo protein-genome interactions using tethered DNA adenine methyltransferase. Methods Enzymol. 410, 342-359. 
Guelen, L., Pagie, L., Brasset, E., Meuleman, W., Faza, M.B., Talhout, W., Eussen, B.H., de Klein, A., Wessels, L., de Laat, W., et al. (2008). Domain organization of human chromosomes revealed by mapping of nuclear lamina interactions. Nature 453, 948-951.

Heessen, S., and Fornerod, M. (2007). The inner nuclear envelope as a transcription factor resting place. EMBO Rep. 8, 914-919.

Hewitt, S.L., High, F.A., Reiner, S.L., Fisher, A.G., and Merkenschlager, M. (2004). Nuclear repositioning marks the selective exclusion of lineage-inappropriate transcription factor loci during $\mathrm{T}$ helper cell differentiation. Eur. J. Immunol. 34, 3604-3613.

Hochstrasser, M., Mathog, D., Gruenbaum, Y., Saumweber, H., and Sedat, J.W. (1986). Spatial organization of chromosomes in the salivary gland nuclei of Drosophila melanogaster. J. Cell Biol. 102, 112-123.

Hochstrasser, M., and Sedat, J.W. (1987). Threedimensional organization of Drosophila melanogaster interphase nuclei. II. Chromosome spatial organization and gene regulation. J. Cell Biol. 104, 1471-1483.

Höger, T.H., Krohne, G., and Kleinschmidt, J.A. (1991). Interaction of Xenopus lamins A and LII with chromatin in vitro mediated by a sequence element in the carboxyterminal domain. Exp. Cell Res. 197, 280-289.

Holaska, J.M., and Wilson, K.L. (2007). An emerin "proteome": purification of distinct emerin-containing complexes from HeLa cells suggests molecular basis for diverse roles including gene regulation, mRNA splicing, signaling, mechanosensing, and nuclear architecture. Biochem. 46, 8897-8908.

Hu, Q., Kwon, Y.-S., Nunez, E., Cardamone, M.D., Hutt, K.R., Ohgi, K.A., Garcia-Bassets, I., Rose, D.W., Glass, C.K., Rosenfeld, M.G., et al. (2008). Enhancing nuclear receptor-induced transcription requires nuclear motor and LSD1-dependent gene networking in interchromatin granules. Proc. Natl. Acad. Sci. USA 105, 19199-19204.

Ikegami, K., Egelhofer, T.A., Strome, S., and Lieb, J.D. (2011). Caenorhabditis elegans chromosome arms are anchored to the nuclear membrane via discontinuous association with LEM-2. Genome Biol. 11, R120.

Imai, S., Nishibayashi, S., Takao, K., Tomifuji, M., Fujino, T., Hasegawa, M., and Takano, T. (1997). Dissociation of Oct-1 from the nuclear peripheral structure induces the cellular aging-associated collagenase gene expression. Mol. Biol. Cell 8, 2407-2419.

Kalmykova, A.I., Nurminsky, D.I., Ryzhov, D.V., and Shevelyov, Y.Y. (2005) Regulated chromatin domain comprising cluster of co-expressed genes in Drosophila melanogaster. Nucleic Acids Res. 33, 1435-1444.

Kalverda, B., Pickersgill, H., Shloma, V.V., and Fornerod, M. (2010). Nucleoporins directly stimulate expression of developmental and cell-cycle genes inside the nucleoplasm. Cell 140, 360-371.

Kiseleva, E., Drummond, S.P., Goldberg, M.W., Rutherford, S.A., Allen, T.D., and Wilson, K.L. (2004). Actin- and protein-41-containing filaments link nuclear pore complexes to subnuclear organelles in Xenopus oocyte nuclei. J. Cell Sci. 117, 2481-2490.

Köhler, A., Schneider, M., Cabal, G.G., Nehrbass, U., and Hurt, E. (2008). Yeast Ataxin-7 links histone deubiquitination with gene gating and mRNA export. Nature Cell Biol. 10, 707-715.
Kosak, S.T., Scalzo, D., Alworth, S.V., Li, F., Palmer, S., Enver, T., Lee, J.S., and Groudine, M. (2007). Coordinate gene regulation during hematopoiesis is related to genomic organization. PLoS Biol. 5, e309.

Kosak, S.T., Skok, J.A., Medina, K.L., Riblet, R., Le Beau, M.M., Fisher, A.G., and Singh, H. (2002). Subnuclear compartmentalization of immunoglobulin loci during lymphocyte development. Science 296, 158-162.

Krajewski, W.A., and Becker, P.B. (1998). Reconstitution of hyperacetylated, DNase I-sensitive chromatin characterized by high conformational flexibility of nucleosomal DNA. Proc. Natl. Acad. Sci. USA 95, 15401545.

Kramer, J.A., McCarrey, J.R., Djakiew, D., and Krawetz, S.A. (1998). Differentiation: the selective potentiation of chromatin domains. Development 125, 4749-4755.

Kumaran, R.I., and Spector, D.L. (2008). A genetic locus targeted to the nuclear periphery in living cells maintains its transcriptional competence. J. Cell Biol. 180, 51-65.

Küpper, K., Kölbl, A., Biener, D., Dittrich, S., von Hase, J., Thormeyer, T., Fiegler, H., Carter, N.P., Speicher, M.R., Cremer, T., et al. (2007). Radial chromatin positioning is shaped by local gene density, not by gene expression. Chromosoma 116, 285-306.

Kurshakova, M.M., Krasnov, A.N., Kopytova, D.V., Shidlovskii, Y.V., Nikolenko, J.V., Nabirochkina, E.N., Spehner, D., Schultz, P., Tora, L., and Georgieva, S.G. (2007). SAGA and a novel Drosophila export complex anchor efficient transcription and mRNA export to NPC. EMBO J. 26, 4956-4965.

Lee, H.Y., Johnson, K.D., Boyer, M.E., and Bresnick, E.H. (2011). Relocalizing genetic loci into specific subnuclear neighborhoods. J. Biol. Chem. 286, 18834-18844.

Lercher, M.J., Urrutia, A.O., and Hurst, L.D. (2002). Clustering of housekeeping genes provides a unified model of gene order in the human genome. Nat. Genet. 31, 180-183.

Lieberman-Aiden, E., van Berkum, N.L., Williams, L., Imakaev, M., Ragoczy, T., Telling, A., Amit, I., Lajoie, B.R., Sabo, P.J., Dorschner, M.O., et al. (2009) Comprehensive mapping of long-range interactions reveals folding principles of the human genome. Science 326, 289-293.

Light, W.H., Brickner, D.G., Brand, V.R., and Brickner, J.H. (2010). Interaction of a DNA zip code with the nuclear pore complex promotes H2A.Z incorporation and INO1 transcriptional memory. Mol. Cell 40, 112-125.

Lowenstein, M.G., Goddard, T.D., and Sedat, J.W. (2004). Long-range interphase chromosome organization in Drosophila: a study using color barcoded fluorescence in situ hybridization and structural clustering analysis. Mol. Biol. Cell 15, 5678-5692.

Luderus, M.E., den Blaauwen, J.L., de Smit, O.J., Compton, D.A., and van Driel, R. (1994). Binding of matrix attachment regions to lamin polymers involves singlestranded regions and the minor groove. Mol. Cell. Biol. 14, 6297-6305.

Luo, L., Gassman, K.L., Petell, L.M., Wilson, C.L., Bewersdorf, J., and Shopland, L.S. (2009). The nuclear periphery of embryonic stem cells is a transcriptionally permissive and repressive compartment. J. Cell Sci. 122, 3729-3737.

Makatsori, D., Kourmouli, N., Polioudaki, H., Shultz, L.D., McLean, K., Theodoropoulos, P.A., Singh, P.B., and 
Georgatos, S.D. (2004). The inner nuclear membrane protein lamin B receptor forms distinct microdomains and links epigenetically marked chromatin to the nuclear envelope. J. Biol. Chem. 279, 25567-25573.

Malhas, A.N., Lee, C.F., and Vaux, D.J. (2009). Lamin B1 controls oxidative stress responses via Oct-1. J. Cell Biol. 184, 45-55.

Marshall, W.F., Dernburg, A.F., Harmon, B., Agard, D.A., and Sedat, J.W. (1996). Specific interactions of chromatin with the nuclear envelope: positional determination within the nucleus in Drosophila melanogaster. Mol. Biol. Cell 7, 825-842.

Mathog, D., and Sedat, J.W. (1989). The three-dimensional organization of polytene nuclei in male Drosophila melanogaster with compound $\mathrm{XY}$ or ring $\mathrm{X}$ chromosomes. Genetics 121, 293-311.

Mayer, R., Brero, A., von Hase, J., Schroeder, T., Cremer, T., and Dietzel, S. (2005). Common themes and cell type specific variations of higher order chromatin arrangements in the mouse. BMC Cell Biol. 6, 44.

Mehta, I.S., Amira, M., Harvey, A.J., and Bridger, J.M. (2010). Rapid chromosome territory relocation by nuclear motor activity in response to serum removal in primary human fibroblasts. Genome Biol. 11, R5.

Meister, P., Towbin, B.D., Pike, B.L., Ponti, A., and Gasser, S.M. (2010). The spatial dynamics of tissue-specific promoters during $C$. elegans development. Genes Dev. 24, 766-782.

Melcer, S., Gruenbaum, Y., and Krohne, G. (2007). Invertebrate lamins. Exp. Cell Res. 313, 2157-2166.

Mendjan, S., Taipale, M., Kind, J., Holz, H., Gebhardt, P., Schelder, M., Vermeulen, M., Buscaino, A., Duncan, K., Mueller, J., et al. (2006). Nuclear pore components are involved in the transcriptional regulation of dosage compensation in Drosophila. Mol. Cell 21, 811-823.

Miller, M.A., Cutter, A.D., Yamamoto, I., Ward, S., and Greenstein, D. (2004). Clustered organization of reproductive genes in the $C$. elegans genome. Curr. Biol. 14, 1284-1290.

Myers, F.A., Chong, W., Evans, D.R., Thorne, A.W., and Crane-Robinson, C. (2003). Acetylation of histone H2B mirrors that of $\mathrm{H} 4$ and $\mathrm{H} 3$ at the chicken $\beta$-globin locus but not at housekeeping genes. J. Biol. Chem. 278, 36315-36322.

Nelander, S., Larsson, E., Kristiansson, E., Månsson, R., Nerman, O., Sigvardsson, M., Mostad, P., and Lindahl, P. (2005). Predictive screening for regulators of conserved functional gene modules (gene batteries) in mammals. BMC Genomics 6, 68.

Nielsen, J.A., Hudson, L.D., and Armstrong, R.C. (2002). Nuclear organization in differentiating oligodendrocytes. J. Cell Sci. 115, 4071-4079.

Peric-Hupkes, D., Meuleman, W., Pagie, L., Bruggeman, S.W., Solovei, I., Brugman, W., Gräf, S., Flicek, P., Kerkhoven, R.M., van Lohuizen, M., et al. (2010). Molecular maps of the reorganization of genome-nuclear lamina interactions during differentiation. Mol. Cell 38, 603-613.

Pickersgill, H., Kalverda, B., de Wit, E., Talhout, W., Fornerod, M., and van Steensel, B. (2006). Characterization of the Drosophila melanogaster genome at the nuclear lamina. Nat. Genet 38, 1005-1014.
Pindyurin, A.V., Moorman, C., de Wit, E., Belyakin, S.N., Belyaeva, E.S., Christophides, G.K., Kafatos, F.C., van Steensel, B., and Zhimulev, I.F. (2007). SUUR joins separate subsets of PcG, HP1 and B-type lamin targets in Drosophila. J. Cell Sci. 120, 2344-2351.

Polioudaki, H., Kourmouli, N., Drosou, V., Bakou, A., Theodoropoulos, P.A., Singh, P.B., Giannakouros, T., and Georgatos, S.D. (2001). Histones H3/H4 form a tight complex with the inner nuclear membrane protein LBR and heterochromatin protein 1. EMBO Rep. 2, 920-925.

Prokocimer, M., Davidovich, M., Nissim-Rafinia, M., Wiesel-Motiuk, N., Bar, D., Barkan, R., Meshorer, E., and Gruenbaum, Y. (2009). Nuclear lamins: key regulators of nuclear structure and activities. J. Cell. Mol. Med. 13, 1059-1085.

Ragoczy, T., Bender, M.A., Telling, A., Byron, R., and Groudine, M. (2006). The locus control region is required for association of the murine $\beta$-globin locus with engaged transcription factories during erythroid maturation. Genes Dev. 20, 1447-1457.

Reddy, K.L., Zullo, J.M., Bertolino, E., and Singh, H. (2008). Transcriptional repression mediated by repositioning of genes to the nuclear lamina. Nature 452, 243-247.

Rougemaille, M., Dieppois, G., Kisseleva-Romanova, E., Gudipati, R.K., Lemoine, S., Blugeon, C., Boulay, J., Jensen, T.H., Stutz, F., Devaux, F., et al. (2008). THO/ Sub2p functions to coordinate 3 '-end processing with gene-nuclear pore association. Cell 135, 308-321.

Roy, P.J., Stuart, J.M., Lund, J., and Kim, S.K. (2002). Chromosomal clustering of muscle-expressed genes in Caenorhabditis elegans. Nature 418, 975-979.

Saccone, S., Federico, C., and Bernardi, G. (2002). Localization of the gene-richest and the gene-poorest isochores in the interphase nuclei of mammals and birds. Gene 300, 169-178.

Sadoni, N., Langer, S., Fauth, C., Bernardi, G., Cremer, T., Turner, B.M., and Zink, D. (1999). Nuclear organization of mammalian genomes. Polar chromosome territories build up functionally distinct higher order compartments. J. Cell Biol. 146, 1211-1226.

Schermelleh, L., Carlton, P.M., Haase, S., Shao, L., Winoto, L., Kner, P., Burke, B., Cardoso, M.C., Agard, D.A., Gustafsson, M.G,, Leonhardt, H., and Sedat, J.W. (2008). Subdiffraction multicolor imaging of the nuclear periphery with 3D structured illumination microscopy. Science 320, 1332-1336

Schirmer, E.C., and Foisner, R. (2007). Proteins that associate with lamins: many faces, many functions. Exp. Cell Res. 313, 2167-2179.

Schmid, M., Arib, G., Laemmli, C., Nishikawa, J., Durussel, T., and Laemmli, U.K. (2006). Nup-PI: the nucleoporepromoter interaction of genes in yeast. Mol. Cell 21, 379 391.

Schübeler, D., Francastel, C., Cimbora, D.M., Reik, A., Martin, D.I., and Groudine, M. (2000). Nuclear localization and histone acetylation: a pathway for chromatin opening and transcriptional activation of the human $\beta$-globin locus. Genes Dev. 14, 940-950.

Schwartz, Y.B., Kahn, T.G., Nix, D.A., Li, X.Y., Bourgon, R., Biggin, M., and Pirrotta, V. (2006). Genome-wide analysis of Polycomb targets in Drosophila melanogaster. Nat. Genet. 38, 700-705. 
Semon, M., and Duret, L. (2006). Evolutionary origin and maintenance of coexpressed gene clusters in mammals. Mol. Biol. Evol. 23, 1715-1723.

Shevelyov, Y.Y., Lavrov, S.A., Mikhaylova, L.M., Nurminsky, I.D., Kulathinal, R.J., Egorova, K.S., Rozovsky, Y.M., and Nurminsky, D.I. (2009). The B-type lamin is required for somatic repression of testis-specific gene clusters. Proc. Natl. Acad. Sci. USA 106, 3282-3287.

Singer, G.A., Lloyd, A.T., Huminiecki, L.B., and Wolfe, K.H. (2005). Clusters of coexpressed genes in mammalian genomes are conserved by natural selection. Mol. Biol. Evol. 22, 767-775.

Solovei, I., Kreysing, M., Lanctôt, C., Kösem, S., Peichl, L., Cremer, T., Guck, J., and Joffe, B. (2009). Nuclear architecture of rod photoreceptor cells adapts to vision in mammalian evolution. Cell 137, 356-368.

Somech, R., Shaklai, S., Geller, O., Amariglio, N., Simon, A.J., Rechavi, G., and Gal-Yam, E.N. (2005). The nuclear-envelope protein and transcriptional repressor LAP2 $\beta$ interacts with HDAC3 at the nuclear periphery, and induces histone $\mathrm{H} 4$ deacetylation. J. Cell Sci. 118, 4017-4025.

Spellman, P.T., and Rubin, G.M. (2002). Evidence for large domains of similarly expressed genes in the Drosophila genome. J. Biol. 1, 5.

Stierle, V., Couprie, J., Ostlund, C., Krimm, I., Zinn-Justin, S., Hossenlopp, P., Worman, H.J., Courvalin, J.C., and Duband-Goulet, I. (2003). The carboxyl-terminal region common to lamins $A$ and $C$ contains a DNA binding domain. Biochemistry 42, 4819-4828.

Sutherland, H., and Bickmore, W.A. (2009). Transcription factories: gene expression in unions? Nat. Rev. Genet. 10, 457-466.

Szczerbal, I., Foster, H.A., and Bridger, J.M. (2009). The spatial repositioning of adipogenesis genes is correlated with their expression status in a porcine mesenchymal stem cell adipogenesis model system. Chromosoma 118, 647-663.

Taddei, A., Houwe, G.V, Hediger, F., Kalck, V., Cubizolles, F., Schober, H., and Gasser, S.M. (2006). Nuclear pore association confers optimal expression levels for an inducible yeast gene. Nature 441, 774-778.

Thomson, I., Gilchrist, S., Bickmore, W.A., and Chubb, J.R. (2004). The radial positioning of chromatin is not inherited through mitosis but is established de novo in early $\mathrm{G} 1$. Curr. Biol. 14, 166-172.

Towbin, B.D., Meister, P., Pike, B.L., and Gasser, S.M. (2011). Repetitive transgenes in C. elegans accumulate heterochromatic marks and are sequestered at the nuclear envelope in a copy-number- and lamin-dependent manner. Cold Spring Harb. Symp. Quant. Biol. 75, 555565.

Tumbar, T., and Belmont, A.S. (2001). Interphase movements of a DNA chromosome region modulated by VP16 transcriptional activator. Nat. Cell Biol. 3, 134-139.

Ueda, H.R., Matsumoto, A., Kawamura, M., lino, M., Tanimura, T., and Hashimoto, S. (2002). Genome-wide transcriptional orchestration of circadian rhythms in Drosophila. J. Biol. Chem. 277, 14048-14052.

van Bemmel, J.G., Pagie, L., Braunschweig, U., Brugman, W., Meuleman, W., Kerkhoven, R.M., and van Steensel, B. (2010). The insulator protein SU(HW) fine-tunes nuclear lamina interactions of the Drosophila genome. PLoS One 5, e15013.

van Steensel, B., and Henikoff, S. (2000). Identification of in vivo DNA targets of chromatin proteins using tethered Dam methyltransferase. Nat. Biotechnol. 18, 424-428.

Vaquerizas, J.M., Suyama, R., Kind, J., Miura, K., Luscombe, N.M., and Akhtar, A. (2010). Nuclear pore proteins Nup153 and Megator define transcriptionally active regions in the Drosophila genome. PLoS Genet. 6, e1000846.

Venter, C.J., Adams, M.D., Myers, E.W., Li, P.W., Mural, R.J., Sutton, G.G., Smith, H.O., Yandell, M., Evans, C.A., Holt, R.A., et al. (2001). The sequence of the human genome. Science 291, 1304-1351.

Versteeg, R., van Schaik, B.D., van Batenburg, M.F., Roos, M., Monajemi, R., Caron, H., Bussemaker, H.J., and van Kampen, A.H. (2003). The human transcriptome map reveals extremes in gene density, intron length, GC content, and repeat pattern for domains of highly and weakly expressed genes. Genome Res. 13, 1998-2004.

Vogel, J.H., von Heydebreck, A., Purmann, A., and Sperling, S. (2005). Chromosomal clustering of a human transcriptome reveals regulatory background. BMC Bioinformatics 6, 230.

Walter, J., Schermelleh, L., Cremer, M., Tashiro, S., and Cremer, T. (2003). Chromosome order in HeLa cells changes during mitosis and early $\mathrm{G} 1$, but is stably maintained during subsequent interphase stages. J. Cell Biol. 160, 685-697.

Wen, B., Wu, H., Shinkai, Y., Irizarry, R.A., and Feinberg, A.P. (2009). Large histone H3 lysine 9 dimethylated chromatin blocks distinguish differentiated from embryonic stem cells. Nat. Genet. 41, 246-250.

Wen, B., Wu, H., Shinkai, Y., Irizarry, R.A., and Feinberg, A.P. (2010). Reassessing the abundance of H3K9me2 chromatin domains in embryonic stem cells. Authors reply. Nat. Genet. 42, 5-6.

Williams, E.J., and Bowles, D.J. (2004). Coexpression of neighboring genes in the genome of Arabidopsis thaliana. Genome Res. 14, 1060-1067.

Williams, R.R., Azuara, V., Perry, P., Sauer, S., Dvorkina, M., Jorgensen, H., Roix, J., McQueen, P., Misteli, T., Merkenschlager, M., et al. (2006). Neural induction promotes large-scale chromatin reorganisation of the Mash1 locus. J. Cell Sci. 119, 132-140.

Yamashita, M., Ukai-Tadenuma, M., Kimura, M., Omori, M., Inami, M., Taniguchi, M., and Nakayama, T. (2002). Identification of a conserved GATA3 response element upstream proximal from the interleukin-13 gene locus. J. Biol. Chem. 277, 42399-42408.

Ye, Q., and Worman, H.J. (1996). Interaction between an integral protein of the nuclear envelope inner membrane and human chromodomain proteins homologous to Drosophila HP1. J. Biol. Chem. 271, 14653-14656.

Yokochi, T., Poduch, K., Ryba, T., Lu, J., Hiratani, I., Tachibana, M., Shinkai, Y., and Gilbert, D.M. (2009). G9a selectively represses a class of late-replicating genes at the nuclear periphery. Proc. Natl. Acad. Sci. USA 106, 19363-19368.

Zhimulev, I.F., Semeshin, V.F., Kulichkov, V.A., and Belyaeva, E.S. (1982). Intercalary heterochromatin in Drosophila. I. Localization and general characteristics. Chromosoma 87, 197-228. 
38 Shevelyov and Nurminsky

Zink, D., Amaral, M.D., Englmann, A., Lang, S., Clarke, L.A., Rudolph, C., Alt, F., Luther, K., Braz, C., Sadoni, N., et al. (2004). Transcription-dependent spatial arrangements of CFTR and adjacent genes in human cell nuclei. J. Cell Biol. 166, 815-825. 


\section{Further Reading}

Caister Academic Press is a leading academic publisher of advanced texts in microbiology, molecular biology and medical research. Full details of all our publications at caister.com

- MALDI-TOF Mass Spectrometry in Microbiology Edited by: M Kostrzewa, S Schubert (2016) www.caister.com/malditof

- Aspergillus and Penicillium in the Post-genomic Era Edited by: RP Vries, IB Gelber, MR Andersen (2016) www.caister.com/aspergillus2

- The Bacteriocins: Current Knowledge and Future Prospects Edited by: RL Dorit, SM Roy, MA Riley (2016)

www.caister.com/bacteriocins

- Omics in Plant Disease Resistance Edited by: V Bhadauria (2016) www.caister.com/opd

- Acidophiles: Life in Extremely Acidic Environments Edited by: R Quatrini, DB Johnson (2016) www.caister.com/acidophiles

- Climate Change and Microbial Ecology: Current Research and Future Trend

Edited by: J Marxsen (2016)

www.caister.com/climate

- Biofilms in Bioremediation: Current Research and Emerging Technologies

Edited by: G Lear (2016)

www.caister.com/biorem

- Microalgae: Current Research and Applications Edited by: MN Tsaloglou (2016) www.caister.com/microalgae

- Gas Plasma Sterilization in Microbiology: Theory, Applications, Pitfalls and New Perspectives Edited by: H Shintani, A Sakudo (2016) www.caister.com/gasplasma

- Virus Evolution: Current Research and Future Directions Edited by: SC Weaver, M Denison, M Roossinck, et al. (2016) www.caister.com/virusevol

- Arboviruses: Molecular Biology, Evolution and Control Edited by: N Vasilakis, DJ Gubler (2016) www.caister.com/arbo

- Shigella: Molecular and Cellular Biology Edited by: WD Picking, WL Picking (2016) www.caister.com/shigella

-Aquatic Biofilms: Ecology, Water Quality and Wastewater Treatment

Edited by: AM Romaní, H Guasch, MD Balaguer (2016)

www.caister.com/aquaticbiofilms

- Alphaviruses: Current Biology

Edited by: S Mahalingam, L Herrero, B Herring (2016)

www.caister.com/alpha

- Thermophilic Microorganisms

Edited by: F Li (2015)

www.caister.com/thermophile
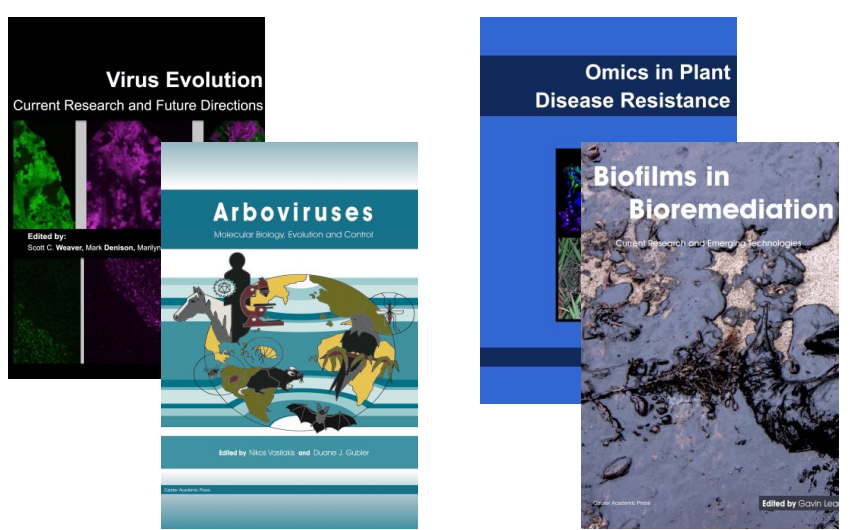
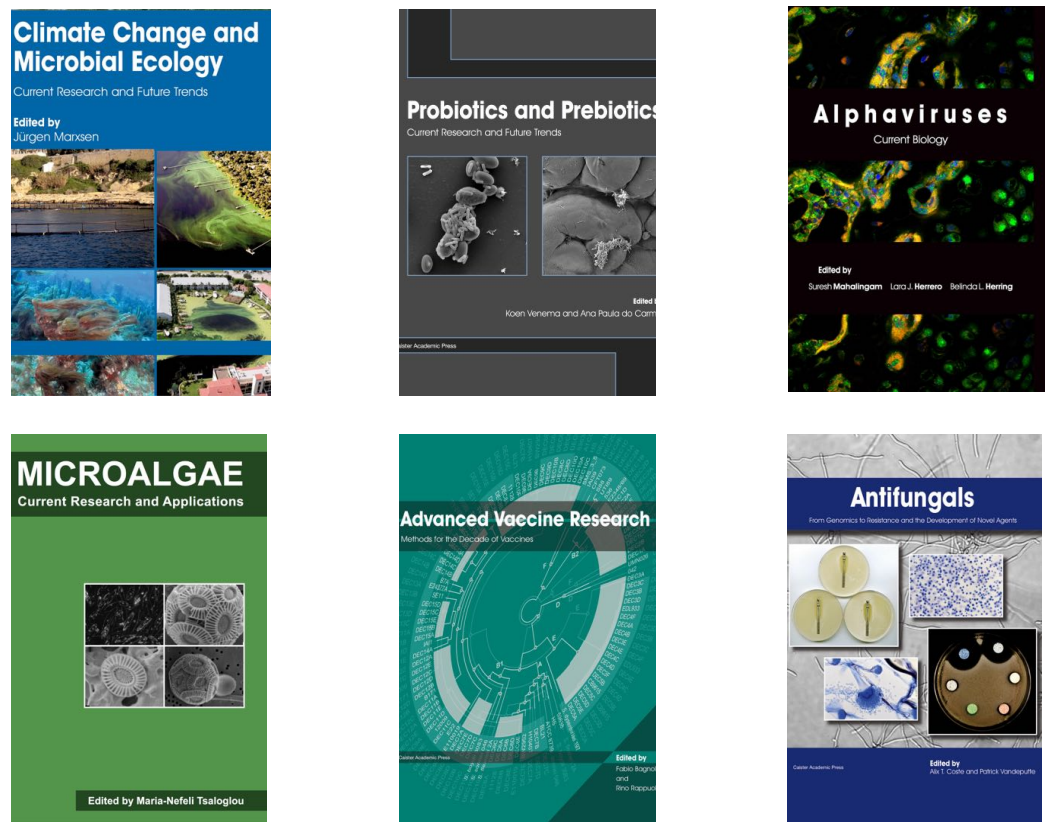

- Flow Cytometry in Microbiology: Technology and Applications Edited by: MG Wilkinson (2015) www.caister.com/flow

- Probiotics and Prebiotics: Current Research and Future Trends Edited by: K Venema, AP Carmo (2015) www.caister.com/probiotics

- Epigenetics: Current Research and Emerging Trends Edited by: BP Chadwick (2015) www.caister.com/epigenetics2015

- Corynebacterium glutamicum: From Systems Biology to Biotechnological Applications

Edited by: A Burkovski (2015)

www.caister.com/cory2

- Advanced Vaccine Research Methods for the Decade of Vaccines

Edited by: F Bagnoli, R Rappuoli (2015)

www.caister.com/vaccines

- Antifungals: From Genomics to Resistance and the Development of Novel Agents

Edited by: AT Coste, P Vandeputte (2015)

www.caister.com/antifungals

- Bacteria-Plant Interactions: Advanced Research and Future Trends Edited by: J Murillo, BA Vinatzer, RW Jackson, et al. (2015) www.caister.com/bacteria-plant

\section{- Aeromonas}

Edited by: J Graf (2015)

www.caister.com/aeromonas

- Antibiotics: Current Innovations and Future Trends

Edited by: S Sánchez, AL Demain (2015)

www.caister.com/antibiotics

- Leishmania: Current Biology and Contro Edited by: S Adak, R Datta (2015) www.caister.com/leish2

- Acanthamoeba: Biology and Pathogenesis (2nd edition) Author: NA Khan (2015)

www.caister.com/acanthamoeba2

- Microarrays: Current Technology, Innovations and Applications Edited by: Z He (2014)

www.caister.com/microarrays2

- Metagenomics of the Microbial Nitrogen Cycle: Theory, Methods and Applications

Edited by: D Marco (2014)

www.caister.com/n2 